\title{
СТРАТЕГИЯ СОЦИАЛЬНОГО ПАРТНЁРСТВА В ХХІ ВЕКЕ
}

Аннотация. В любом государстве, будь то высокоразвитое индустриальное общество или страна с переходной экономикой, в ходе его развития и совершенствования все группь и слои стремятся обеспечить свои интересь и благосостояние и закрепить свои права. Принуждённые взаимодействовать друг с другом, для реализации этих ичелей они прибегают $\kappa$ проверенному, действенному инструменту - социальному партнёрству. Политика социального партнёрства лежит в основе отношений между силами, определяюшими социально-экономическое развитие современного общества: трудом, капиталом, государственной вла-стью. Его использование позволяет воздействовать на отдельнье части сложного механиз-ма сочиильной и политической структуры общества, что в конечном итоге создаёт возможности для обеспечения их взаимодействия с учётом интересов каждого.

Ключевые слова: сочиальное партнёрство, взаимодействие между трудом и капиталом, соичиальный аудит, Европейские советь по труду, ТНК, профсоюзы, устойчивое развитие, глобализачия, сочиальные кодексы, кодексы поведения, Европейская сочииальная модель, Европейская сочиальная политика, Глобальный договор, ООН.

\section{Социальное партнёрство - ключ к устойчивому развитию общества}

Социальное партнёрство можно определить как форму общественного компромисса для решения общенациональных проблем, всё чаще демонстрирующих тенденцию перехода на международный уровень.

Отличительной чертой социального партнёрства XXI в. является то, что оно представляет собой уже не столько способ социальной защиты трудящихся, сколько такой путь взаимодействия между наёмными работниками и собственниками капитала, который позволяет сконцентрировать усилия общества на задачах, решение которых жизненно необходимо для устойчивого развития общества. Масштабы такого партнёрства могут быть различны: цех, предприятие, отрасль, корпорация, государство. При этом для каждого из партнёров необходимо чётко обозначить участок работы и степень возлагаемой на него ответственности. Причём, когда говорится об ответственности, то подразумевается ответственность не только перед теми, чьи интересы представляет каждый из партнёров, но и перед обществом в целом.

Социальное партнёрство выросло из соглашений, заключаемых администрацией отдельных предприятий с профсоюзами. Интересно, что возникновение политики социального партнёрства было инициировано предпринимателями, а профсоюзы, традиционно выступавшие их оппонентами, были вынуждены принять её как необходимость. Но результаты,

\footnotetext{
(C) Каргалова Марина Викторовна - доктор исторических наук, главный научный сотрудник, руководитель Центра проблем социального развития Европы Отдела социально-политических исследований, Институт Европы РАН. Адрес: 125009, Россия, Москва, ул. Моховая, д. 11, cтp. 3.E-mail: mkargalova@mail.ru.
}

DOI: http://dx.doi.org/10.15211/vestnikieran420194954 
достигнутые путём социального партнёрства, заставили организации трудящихся по достоинству оце-нить потенциал и перспективность этой формы взаимодействия.

Принимая во внимание тот факт, что задачи, функции, интересы социальных партнёров неизбежно отличались между собой и нередко вступали в противоречие, разработчики политики социального партнёрства стали стремиться преодолеть их и найти формы взаимодейст-вия, позволяющие партнёрам конструктивно сотрудничать для решения общей задачи. Задача эта - поступательный рост экономики, усиление конкурентоспособности предприятий и обеспечение устойчивого развития общества, то есть такого развития, которое позволило бы в той или иной мере удовлетворить потребности всех участников партнёрства.

По мере развития системы социального партнёрства к диалогу труда и капитала присоединились третьи стороны в лице государственных структур разных уровней, организаций гражданского общества и т.п. В конечном итоге предприниматели, стремящиеся в первую очередь к получению прибыли, оказались вовлечены в деятельность по созданию социального климата, обеспечивающего условия для эффективной работы предприятия.

С момента своего возникновения социальное партнёрство прошло длинный и непростой путь, вместе с профсоюзным движением переживая периоды взлётов и падений, преодолевая объективные и субъективные барьеры. В настоящее время система коллективных догово́ров и соглашений высоко развита: социальные партнёры в их рамках эффективно сотрудничают на любых уровнях вплоть до международного.

\section{Формы и структуры партнерства}

1. Социальный аудит;

2. Европейские советы по труду (ЕСТ);

3. Государственно-частное социальное партнёрство;

4. Формы партнёрства, связанные с инновационным развитием на международном уро-

BHe.

В ходе глобализации расширяется круг интересов оппонентов капитала - наёмных работников, которые теперь открыто требуют доступ к контролю над распределением доходов и право наблюдения за бюджетным финансированием. Такой контроль может осуществляться путём социального аудита.

Социальный аудит получил широкое распространение и стал эффективным инструментом в руках партнёров в 80-х гг. XX в. Первая европейская программа по социальному аудиту была разработана в 1997 г. На данный момент реализованы уже пять таких международных программ с участием представителей Франции, Бельгии, Италии, Испании, Швеции, Великобритании ${ }^{1}$.

Хорошо зарекомендовала себя такая форма социального партнёрства, как Европейские советы по труду (ЕСТ). ЕСТ впервые появились в конце 1980-х гг. на крупных европейских ТНК, имевших филиалы в разных регионах мира и испытывавших потребность в новых формах социального партнёрства. То, что необходимость нахождения таких форм осознали именно ТНК неудивительно, ведь по своей природе именно они должны обладать глобальным видением проблем и выбирать соответствующие формы управления для их решения. Собственники и администрация ТНК вынуждены вступать в партнёрское взаимодействие с особенно крупными и влиятельными профсоюзными объединениями, поэтому именно там можно наблюдать появление новых форм социального партнёрства, отвечающих вызовам времени.

\footnotetext{
${ }^{1}$ Социальная Европа в XXI веке. Под ред. М.В. Каргаловой. М., 2011.
}

Научно-аналитический вестник ИЕ РАН, 2019, №4 
Создаваемые в соответствии с Директивой КЕС от 1994 г. ЕСТ действуют в русле законодательства Сообщества в крупных компаниях, получивших статус «европейских». На данный момент на это звание претендует значительное число компаний, оценивших перспективность ЕСТ в качестве социального партнёрства нового типа.

Другая ранее неизвестная форма партнёрства появилась после того, как Инновационный Лиссабонский саммит (2005) принял стратегическую программу «Европа-2020» ${ }^{1}$, в рамках которой особое место занимает развитие и поддержка новой формы социального партнёрства - государственно-частного. Также стратегия «Европа-2020» предусматривает развитие новых форм партнёрства, связанных с инновационным развитием на международном уровне ${ }^{2}$.

Проблемами, связанными с новыми условиями и вызовами глобализации, а также социальной ответственностью, вплотную занимаются международные организации. Ещё в 1999 г. Генеральный секретарь ООН выступил с идеей принятия Глобального договора, где призвал вовлечь ТНК в деятельность, связанную с принятием стандартов справедливости в трудовых отношениях, уважением прав человека и охраной природы. Крупным корпорациям было предложено воплотить эти принципы в конкретные формы управления.

К 2000 г. по данным Евростата более 50 ТНК официально приняли на себя обязательства по практическому осуществлению Глобального договора. К 2005 г. к ним присоединились 100 ведущих ТНК и более 1000 других компаний в разных регионах мира. Видимо, не чисто альтруистские настроения руководили ими. Скорее всего они просчитали перспективы несомненной выгоды, связанной с обстановкой открытости рынков, социальной стабильностью, пользой от рационального использования природных ресурсов.

\section{Социальные кодексы}

Помимо уже упоминавшихся коллективных догово́ров и соглашений в крупных компаниях получила распространение практика принятия «Социальных кодексов» или «Кодексов поведения», как их иногда называют на Западе. В них обозначаются стратегические направления развития компании, фиксируются основные параметры социальной деятельности на предприятиях, а также оговариваются формы ответственности труда и бизнеса за создание благоприятного социального климата, способствующего увеличению эффективности производства и обеспечению социальной защиты персонала. Данные документы помогают управлять процессом реализации социальной ответственности сторон, а также способствуют формированию новой трудовой этики.

Однако зачастую эти документы являются декларативными и не имеют юридической силы. Эта проблема до сих пор остаётся нерешённой. Отсюда возникает необходимость создать механизмы реализации обозначенных ими задач и контроля за их исполнением. Появят-ся ли подобные механизмы, зависит от принципиальной позиции руководства компании, её отношения к кодексу, а также от активности и авторитета профсоюзов.

Популярность «Социальных кодексов» растёт, что свидетельствует о росте осознания взаимосвязи между социальным климатом и эффективностью управляющим персоналом предприятий». Однако ценность «Социальных кодексов» состоит не только в создании комфортного социального климата на предприятии, не только в обеспечении приоритетных позиций на национальном рынке, налаживании продуктивных отношений с государственной

\footnotetext{
1 The European Semester. URL: http://ec.europa.eu/europe2020/in-a-mutshell/priorities/smart-growth/index_enhtm (дата обращения: 16.07.2019).

${ }^{2}$ Социальная Европа в XXI веке. Часть I. Социальный стержень Европы. Отв. ред. М.В. Каргалова. ДИЕ РАН, №246, 2009.
} 
властью, но и в явной привлекательности предприятия, обладающего им, для зарубежных партнёров. Кодексы показывают уровень корпоративной культуры. Не случайно в последнее время всё большее внимания в них уделяется социально-ответственному инвестированию.

Должным образом оформленный корпоративный кодекс, с одной стороны, подчёркивает роль предприятия как фактора эффективного развития общества, а с другой является показателем надёжности данной компании или предприятия в качестве партнёра на глобальном рынке. Наличие у компании собственного «Социального кодекса», ориентированного на меж-дународные стандарты, способствует формированию положительного имиджа предприятия на международной арене, поскольку такой кодекс будет отражать соответствие корпоративной политики новым социальным технологиям и экономическим инновациям, а также свидетельствовать о наличии стабильного социального климата на предприятии.

Разработка кодекса, отвечающего современным требованиям, и снабжение его поддерживающими механизмами контроля отвечает стратегии социального партнёрства нового типа. Ведь такой документ помимо установления норм и правил внутри компании выполняет и более широкие задачи. Он заявляет о компании как о социально-ответственном члене общест-ва, претендующем на то, чтобы представлять интересы страны на международном уровне, не говоря уже об усилении политического влияния в собственной стране.

Необходимо отметить неоценимую значимость деятельности профсоюзов как представителей наёмных работников, наиболее организованной и эффективной силы в системе социального партнёрства.

Коллективные договоры и соглашения фиксируют результаты социального партнёрства в рамках предприятий и отраслей промышленности, отражают эволюцию взаимоотношений администрации и организаций трудящихся. Они шаг за шагом расширяют сферу взаимодоговорённостей, отражают расстановку сил между социальными партнёрами.

\section{Разработка социального партнёрства на коммунитарном уровне}

Выработанная европейским бизнесом «упреждающая стратегия» была нацелена на предупреждение возможных социальных конфликтов, урегулирование неизбежных разногласий, продиктованных различиями в позициях партнеров. Следует признать, что, несмотря на очевидные успехи европейской политики социального партнёрства и тот факт, что требования, сформулированные в коллективных договорах, после саммита в Ницце (2007) включаются в официальные документы Евросоюза, противостояние социальных партнёров не исчезло, хотя приняло другие формы и выражается по-иному.

Опубликованная в 2001 г. Зелёная книга о корпоративной социальной ответственности ${ }^{1}$, а затем и её продолжение - Европейская социальная политика: путь для Союза ${ }^{2}$ подробнейшим образом рассматривают новую ситуацию и анализируют долю социальной ответственности, которая ложится как на предпринимателей, работающих на межнациональном пространстве, так и на их оппонентов - представительные организации трудящихся.

Переживающий сложные времена Европейский союз стоит перед дилеммой: сохранить восприятие Европы как региона, наиболее привлекательного для проживания, обеспечивая

\footnotetext{
${ }_{1}^{1}$ Green paper European social policy. Options for the Union. Brussels Luxemburg. 1994.

2 Европейский Союз: прошлое, настоящее, будущее. Социальная политика. Под ред. Борко Ю.А., Каргаловой М.В., Ковальского Н.А. М., 1996. С. 220-224.
} 
надёжную социальную защиту населения традиционными методами, или стремиться идти в ногу со временем, постоянно предлагающим новшества.

\section{Роль Европейской социальной модели}

Политика социального партнёрства способна вызвать ожесточённые споры и дискуссии. Она является важной частью пресловутой Европейской социальной модели (ЕСМ). А та уже подвергается критике и трансформациям, хотя носит название «социальный стержень Европы». Оценки стратегии и эффективность реформ зачастую бывают диаметрально противоположными со стороны внешних партнеров и внутренней оппозиции.

Политике социального партнёрства, в особенности её стратегии, предстоит длительная и тщательная разработка прежде, чем они будут соответствовать запросам их участников.

\section{Выводы}

Появление цифровой экономики и её влияние на социальную обстановку выявило массу новых проблем, без решения которых невозможно дальнейшее развитие современного об-щества. В новых условиях следует признать неудачными попытки использовать традиционные способы преодоления кризисов в экономике и борьбы с негативными социальными последствиями.

Следует выработать иные методы и подходы в управлении экономикой и обществом в целом. Успешность выполнения этой задачи зависит от способности политических элит собрать и использовать потенциал сил, которые способны ответить на вызовы XXI в. и справиться с поставленными перед ними задачами. В первую очередь, речь идёт о таких зарекомендовавших себя и способных на трансформацию организациях, как партии, профсоюзы, отраслевые, региональные и другие массовые объединения.

Без глубокой качественной перестройки трудовых и социальных отношений и структур общества успехи таких процессов маловероятны. Отсюда - важное, если не решающее значение идеологической работы, развитие массового сознания, повышение политической культуры, воспитание личности, осознание мотивации труда и его перспектив.

\section{Список литературы}

Социальная Европа в XXI веке. Под ред. М.В. Каргаловой. М., 2011.

Социальная Европа в XXI веке. Часть I. Социальный стержень Европы. Отв. ред. М.В. Каргалова. ДИЕ РАН, №246. М., 2009.

Европейский Союз: прошлое, настоящее, будущее. Социальная политика. Под ред. Борко Ю.А., Каргаловой М.В., Ковальского Н.А. М., 1996. С. 220-224.

\section{References}

Social'naya Evropa v XXI veke. Pod red. M.V. Kargalovoj. M., 2011.

The European Semester. URL: http://ec.europa.eu/europe2020/in-a-mutshell/priorities/smartgrowth/index_enhtm (access: 16.07.2019).

Social'naya Evropa v XXI veke. Chast' I. Social'nyj sterzhen' Evropy. Otv. red. M.V. Kargalova. DIE RAN, №246. M., 2009.

Green paper European social policy. Options for the Union. Brussels Luxemburg. 1994.

Evropejskij Soyuz: proshloe, nastoyashchee, budushchee. Social'naya politika. Pod red. Borko Yu.A., Kargalovoj M.V., Koval'skogo N.A. M., 1996. S. 220-224.

Научно-аналитический вестник ИЕ РАН, 2019, №4 


\section{Strategy of Social Partnership in XXI century}

Author. Marina Kargalova, Doctor of Sciences (History), Chief Research Associate, Institute of Europe, Russian Academy of Sciences. Address: 11-3, Mokhovaya str., Moscow, Russia, 125009. E-mail: mkargalova@mail.ru.

Abstract. In any state: either in a high-developed industrial society or in a transition economy state in the course of its development all groups and strata strive to ensure theirs interests and welfare and secure their rights. Forced to cooperate with each other they use such a proven effective instrument as social partnership so as to fulfil their goals. The policy of social partnership underlies the relations between the forces that determine socio-economic development of the modern society: labor, capital, state power. The use of it makes it possible to influence separate parts of the complex mechanism of socio-political societal structure which eventually creates opportunities for ensuring their interaction taking into account the interests of each.

Key words: social partnership, interaction between labor and capital, social audit, European Labor Councils, labor unions, sustainable development, globalization, Social Codes, Codes of Conduct, the European social model, the European Social Policy, the Global Compact, the UN.

DOI: http://dx.doi.org/10.15211/vestnikieran420194954 